ственных и муниципальных нужд подрывает не только антикоррупционные основы, но и экономику всей страны.

1 Ходасевич О. Н., Шаламова Е. Ю. Коррупция в сфере государственных закупок // Концепт. 2018. № 3. С. 30-36.

2 Бочкова Ю. А. Сговоры на торгах при осуществлении государственных закупок // Проблемы современной экономики. 2014. № 4. С. 117-120.

3 Дараган В. В. Преступность в сфере государственных закупок и ее взаимосвязь с коррупционной преступностью // Вестник Нижегородской академии МВД России. 2015. № 3. С. 61-68.

4 Ревина С.Н., Паулов П.А., Борякин Д.В. Управление закупками и заказами учебное пособие // Издательство Саиарского государственного экономического университета. 2019. С. 161.

\title{
THE PROBLEM OF CRIMINAL VIOLATION OF THE PRINCIPLES OF COMPETITION WHEN IMPLEMENTING PURCHASES FOR STATE AND MUNICIPAL NEEDS
}

\author{
(C) 2020 Dakashev Mehadin Mukhtarovich \\ Student \\ Samara State University of Economics \\ E-mail: mexadin.dakashev@mail.ru
}

Keywords: competition, state, municipal, contract, competition, corruption, order.

This article will examine certain types of corruption violations of the principles of competition during the tender in the field of procurement for state and municipal needs. Why will we analyze the manifestation of the corruption component in the implementation of state and municipal orders.

УДК 347.19

Код РИНЦ 10.00.00

\section{СПОСОБЫ ЗАЩИТЫ ПРАВ АКЦИОНЕРОВ НА УПРАВЛЕНИЕ ДЕЛАМИ АКЦИОНЕРНОГО ОБЩЕСТВА}

\author{
(c) 2020 Девяткина Анна Юрьевна* \\ магистрант \\ Самарский государственный экономический университет \\ E-mail: anna.devyatkina.1997@mail.ru
}

Ключевые слова: акционер, права акционера, управление акционерным обществом, решение общего собрания, защита прав акционеров, голосующие акции, способы защиты прав, уполномоченный орган, внеочередное общее собрание акционеров, корпоративное право. доцент.

* Научный руководитель - Дельцова Наталья Вячеславовна, кандидат юридических наук, 
Статья посвящена исследованию современного состояния и правового регулирования института защиты прав акционеров на управление акционерным обществом. Актуальность данной темы обусловлена развитием предпринимательских отношений. В статье анализируются данные права и способы их защиты, также отмечена необходимость внесения изменений в законодательство, которое регулирует способы защиты права на участие в управлении акционерным обществом, в частности ст. 49, 53, 55 Федерального закона "Об акционерных обществах". Изучение актуальных аспектов управления акционерными обществами будет способствовать более совершенной защите прав акционеров на управление делами акционерного общества.

К сфрере регулирования корпоративного права относятся организационно-управленческие отношения внутри юридических лиц, непосредственно связанные с формированием и выражением воли юридического лица. Право акционеров на управление делами акционерного общества (далее АО) относится к одним из важных прав акционеров, закрепленных действующим законодательством, и имеет корпоративно-правовую природу.

В современной научно-теоретической литературе право акционера на участие в управлении акционерным обществом представляется как структурное образование, институт, содержащий целый комплекс взаимосвязанных элементов. Отечественный законодатель при закреплении прав акционеров на управление АO определил структуру данного субъективного права и обозначил список юридических возможностей акционеров. В этом случае толкователь закона имеет возможность, анализируя различные нормы самостоятельно определить, что может входить в этот перечень. К сожалению, на практике нередко такая трактовка законодательства способствует его расширенному толкованию.

Исследователи корпоративного законодательства, опираясь на действующие нормы, к праву акционеров на управление акционерным обществом, закрепленному в законодательстве относят в целом практически идентичный перечень.

Д.В. Ломакин относит к правам акционеров на управление АО: "правомочия требовать созыва общего собрания акционеров, принимать участие в подготовке проведения собрания, а также принимать участие непосредственно в самом общем собрании, правомочие голосования, а также правомочие быть избранным в органы акционерного общества.

Защита права акционера на управление делами акционерного общества является важнейшей задачей, поскольку в акционерном законодательстве Российской Федерации содержатся предпосылки для нарушения прав органами управления. Правоприменительная практика свидетельствует о многочисленных нарушениях рассматриваемых прав, что означает необходимость обеспечения повышения эффрективности действия механизма защиты прав акционеров на управление акционерным обществом.

Защита прав акционера на управление представляет собой совокупность правовых методов и средств, которыми может воспользоваться акционер, право на управление акционерным обществом которого было нарушено.

К самым распространенным способам защиты рассматриваемых прав акционеров относят:

1) понуждение к проведению общего собрания акционерного общества.

Этот способ применяется в ситуациях, когда лицо, которое в силу закона обладает правом настаивать на созыве внеочередного общего собрания, воспользовалось им, но получило отказ или вовсе не получило ответа. В такой ситуации лицо вправе обратиться 
в суд с иском о понуждении к проведению внеочередного собрания общества. Этот метод применим только к созыву внеочередных собраний.

В последние годы правоприменительная практика в отношении данного способа защиты права акционеров на управлении акционерным обществом складывается следующим образом:

- иски о понуждении акционерного общества провести внеочередное общее собрание предъявляют, как правило, миноритарные акционеры;

- истец заявляет требование предоставить ему право проведения собрания, значительно реже обязанность его организации возлагается на единый исполнительный орган, ревизионную комиссию или другого акционера;

- суды неизменно обращают решения к немедленному исполнению, что целесообразно, поскольку возможные потери времени на оспаривание решения обычно обесценивают управленческую необходимость проведения данного мероприятия;

- мера конкретизации судебного акта относительно описания порядка проведения общего собрания акционеров неоднозначна. В некоторых судебных решениях отмечается простая ссылка на закон и устав, хотя в ряде решений эта часть излагается достаточно детально, что можно обосновать настойчивостью просительной части иска;

- сохраняется неопределенность в том, должно ли лицо, занимающееся организацией и проведением собрания руководствоваться частными регламентными нормами внутренних положений эмитента 4.

2) понуждение к включению предложенного акционером вопроса в повестку дня общего собрания или кандидата в список кандидатур для избрания в состав органов общества. Этот способ установлен п.6 ст.53 вышеуказанного закона и представляет собой юрисдикционную форму защиты права на участие в управлении обществом, так как он реализуется лишь в судебном порядке.

Автор данной работы полагает, что причиной пропуска срока акционером на обращение в суд с заявлением о защите своих прав может послужить не указание в п.7 ст.55 и п.6 ст.53 Федерального закона "Об акционерных обществах" способа направления решения о созыве или об отказе в созыве собрания акционеров, а также решения об отказе во включении кандидата для избрания в состав органов акционерного общества или во включении вопроса в повестку дня общего собрания акционеров. Данный факт позволяет предположить, что эта проблема будет нивелирована дополнением указанных норм закона следующей редакцией: "заказным письмом с описью вложения и уведомлением о вручении, если иные способы направления, обеспечивающие подтверждение вручения корреспонденции адресату не предусмотрены уставом общества".

Направление адресату заказного письма с уведомлением о вручении необходимо, поскольку это позволяет подтвердить факт получения корреспонденции. А направление письма с описью вложения позволяет доказать, какие именно документы содержало письмо.

В судебной практике встречаются дела², когда акционеры просят включить в повестку внеочередного общего собрания акционеров вопросы, принятие решений по которым согласно п.3 ст.49 Федерального закона "Об акционерных обществах" принимаются "только по предложению совета директоров (наблюдательного совета)". В связи с этим возникает вопрос вправе ли в данной ситуации совет директоров отказать в созыве вне- 
очередного общего собрания, а суд должен отказать в удовлетворении иска о понуждении. В результате правоприменительной деятельности суды отмечают приоритет ст.55 Ф3 "Об акционерных обществах" о праве акционера, являющегося обладателем не менее чем 10 процентов голосующих акций общества, требовать созыва внеочередного общего собрания акционеров над специальными нормами п. 3 ст.49 указанного выше Закона.

3) признание недействительным решения общего собрания акционерного общества. В процессе изучения вопросов правовой защиты акционера на участие в управлении делами акционерного общества автор данной работы пришел к выводу, что действующее законодательство, регулирующее вопросы признания недействительным решения общего собрания, необходимо совершенствовать.

В частности, следует внести изменения в п.7 ст.49 Ф3 "Об акционерных обществах" в части перечисления перечня причин отсутствия акционера на общем собрании акционеров, которые можно считать уважительными. При этом очевидно, что суду необходимо предоставить право оценивать по своему усмотрению и другие причины, по которым акционер не участвовал в голосовании.

Определенную сложность представляют дела, когда акционеру принадлежало право участия в собрании, но к моменту рассмотрения спора в судебной инстанции он участником общества не являлся, поскольку реализовал свои акции. С одной стороны, права такого бывшего участника не могут быть восстановлены, поскольку он более не обладает специальной правоспособностью участника корпорации, представляющей собой предпосылку наличия у него корпоративных прав и законного интереса. С другой стороны, учитывая конкретные обстоятельства дела можно предположить, что недействительным признается решение собрания, которое было принято в период, когда данное лицо являлось участником, и могло влиять на права такого лица, и было бы несправедливо лишить бывшего участника возможности защитить свои права. Соответственно можно сделать промежуточный вывод о том, что потеря статуса акционера не является основанием для лишения его права оспорить решение, которым затрагиваются его права как бывшего участника акционерного общества. Поэтому автор считает, что в п.7 ст.49 ФЗ "Об акционерных обществах" следует закрепить следующее положение: "если решение собрания акционеров акционерного общества затрагивает права бывшего акционера, то прекращение статуса акционера не может служить основанием для лишения его права оспорить подобное решение"5.

Таким образом, защита прав акционеров на участие в управлении акционерным обществом является значимой составляющей корпоративного законодательства. Его совершенствование будет способствовать улучшению деятельности акционерных обществ и гарантировать права на управление его участникам. Для эффективного функционирования рассмотренных способов защиты данного права акционера необходимо внести изменения, указанные в работе, в действующее акционерное законодательство.

1 Федеральный закон от 26.12.1995 N 208-Ф3 "Об акционерных обществах" (ред. от 04.11.2019). - Режим доступа: http://www.consultant.ru/ (дата обращения: 25.02.2020).

2 Постановление Арбитражного суда Волго-Вятского округа от 20 декабря 2016 г. №ф015491/16 - Режим доступа: http://www.consultant.ru/ (дата обращения: 07.03.2020). 
3 Борисов А.Н. Комментарий к Федеральному закону "Об акционерных обществах". - М.: Дело, 2018. - $632 \mathrm{c}$.

4 Осипенко О.В. Актуальные проблемы инструментов корпоративного управления и акционерного права. - М.: Статут, 2018 - Режим доступа: http://www.consultant.ru/ (дата обращения: 03.03.2020).

${ }^{5}$ Белаш Е.А. Некоторые проблемы защиты прав акционеров на управление акционерным обществом. - Режим доступа: http://www.dnevniknauki.ru/ (дата обращения: 05.03.2020).

\title{
WAYS TO PROTECT THE RIGHTS OF SHAREHOLDERS TO MANAGE THE AFFAIRS OF A JOINT-STOCK COMPANY
}

\author{
(C) 2020 Devyatkina Anna Yuryevna \\ Undergraduate \\ Samara State University of Economics \\ E-mail: anna.devyatkina.1997@mail.ru
}

Keywords: shareholder, shareholder rights, management of a joint-stock company, decision of the General meeting, protection of shareholders ' rights, voting shares, methods of protection of rights, authorized body, extraordinary General meeting of shareholders, corporate law.

The article is devoted to the study of the current state and legal regulation of the Institute for the protection of shareholders ' rights to manage a joint-stock company. The relevance of this topic is due to the development of business relations. The article analyzes these rights and ways to protect them, and also notes the need to make changes to the legislation that regulates ways to protect the right to participate in the management of a joint-stock company, in particular articles 49, 53, 55 of the Federal law "on joint-stock companies". The study of current aspects of management of joint-stock companies will help to better protect the rights of shareholders to manage the Affairs of the joint-stock company.

УДК 347

Код РИНЦ 10.00.00

\section{РОБОТИЗИРОВАННЫЕ ТЕХНОЛОГИИ ИСКУССТВЕННОГО ИНТЕЛЛЕКТА В АСПЕКТЕ ПРАВОВОГО РЕГУЛИРОВАНИЯ}

\author{
() 2020 Дельцова Наталья Вячеславовна \\ кандидат юридических наук, доцент \\ Самарский государственный экономический университет \\ E-mail: natdel@mail.ru
}

Ключевые слова: искусственный интеллект, роботизированная система, правовое регулирование, информационные технологии.

Статья посвящена формированию правового регулирования технологий искусственного интеллекта и роботов в Российской Федерации. Рассматриваются имеющиеся действующие норма- 